\title{
Occupational Risk Management In a Mining Enterprise With the Aid of an Improved Matrix Method for Risk Assessment
}

\author{
Gennadiy I. KORSHUNOV ${ }^{1}$, Eugeniy I. KABANOV $V^{2}$ and Michal CEHLÁR ${ }^{3}$
}

Authors' affiliations and addresses: ${ }^{1}$ Saint Petersburg Mining University, Industrial Safety Department, 21st line 2, 199106, St. Petersburg, Russia

e-mail: korshunov_gi@pers.spmi.ru

${ }^{2}$ Saint Petersburg Mining University, Industrial Safety Department, 21st line 2, 199106, St.

Petersburg, Russia

e-mail: kabanov_ei@pers.spmi.ru

${ }^{3}$ Technical University of Košice, Faculty of Mining, Ecology, Process Control and Geotechnology, Letná 9, 042 00, Košice, Slovak Republic

e-mail: michal.cehlar@tuke.sk

*Correspondence:

Eugeniy I. Kabanov, Saint Petersburg Mining University, Industrial Safety Department, 21st line 2, 199106, St. Petersburg, Russia tel.: +7812328 8631

e-mail: kabanov_ei@pers.spmi.ru

\section{Acknowledgment:}

This work was supported by the Saint Petersburg Mining University under contract nо. КПД1-20176

How to cite this article:

Korshunov, G.I., Kabanov, E.I. and Cehlár, M. (2020). Occupational Risk Management In a Mining Enterprise With the Aid of an Improved Matrix Method for Risk Assessment. Acta Montanistica Slovaca, Volume 25 (3), 289-301

DOI:

https://doi.org/10.46544/AMS.v25i3.3

\begin{abstract}
The article is devoted to solving the topical problem of creating a system for occupational risk management in mining enterprises that would be able to function under the conditions of a limitation in the organization's economic and information resources. The study aims to develop an approach of occupational risk management at a mining enterprise based on an improved and fundamentally new matrix method of assessing occupational risks, which allows increasing the efficiency of managerial decision-making. The suggested method is based on a set of methodological approaches aimed at minimizing the drawbacks inherent to standard risk assessment matrices that were identified and studied by the authors in the process of system analysis. In particular, the regression analysis of the experts' evaluations has provided the basis for calculation models of occupational risk assessment, which allow increasing the level of detail in evaluation results. Alongside that, the fact that the suggested method uses intuitively comprehensible continuous variables of probability/damage, on the one hand, reduces the uncertainty in expert assessment, and on the other hand, preserves the visibility and convenience of using the classical matrix method for occupational risk assessment. To optimize the use of the assessment groups' resources, the authors have developed an algorithm for an occupational risk management procedure based on a comprehensive qualitative study of scenarios of the negative impact of hazards on mining enterprise workers. The paper provides recommendations for systematization and inventory of occupational risk analysis results to determine and plan protective measures. We have described the results of the testing of the proposed method received in the course of analysis of the miners' working conditions in the operating coal mines - which indicate an increase in the level of detail of the output data and the possibility of applying a unified approach to the analysis of heterogeneous occupational risks. In addition to that, the paper shows the positive effect achieved by the use of the suggested method compared to the standard matrix assessment of occupational risks.
\end{abstract}

\section{Keywords}

Labour safety, mining enterprise, occupational risk assessment, risk management, risk assessment matrix, expert assessment, injuries, occupational morbidity. 


\section{Introduction}

In the context of active implementation of risk-oriented approach principles when providing labor safety, many mining enterprises encounter the necessity to create occupational risk management systems in the organization's general management structure (Noskov et al., 2020; Rudakov et al., 2020; Skopintseva and Balovtsev, 2020; Pelipenko et al., 2019; Kazanin et al., 2018; Semenov and Kruk, 2017). In these circumstances, one of the most significant problems is choosing an adequate method for occupational risk assessment, which is a basic element of the occupational risk management procedure. As practice shows, at the initial stages of such systems' development, many users tend to give preference to simple qualitative and semi-quantitative methods for occupational risk assessment (Gendler et al., 2020; Kuletskiy et al.,2020), the matrix method of assessment being the most popular one of them.

If used correctly, risk assessment matrices are a useful and efficient analysis tool: they do not require substantial resource mobilization, can be used under conditions of high uncertainty of initial data by experts possessing no specialized knowledge in the field of qualitative risk assessment (statistical analysis, probabilistic modeling). In order to fully exploit the risk matrices' potential, the users must have a clear understanding of this method's drawbacks, which will allow for avoiding serious mistakes during its use.

It is worth mentioning that, from the point of view of occupational risk management, risk matrices do not provide a data volume sufficient for justification of protective measures: they do not answer the question, "What has to be done to reduce the hazard?" because such information is simply not included in the structure of risk matrices. For this reason, risk matrix users may have a gap in understanding between the notions of "risk assessment" and "risk management". In a number of instances, this leads to difficulties in the organization of an occupational risk management system in mining enterprises, which is complicated by the inconsistency in clear methodological recommendations for building such systems.

\section{Literature Review}

Risk assessment matrices: advantages and drawbacks.

Risk matrices are used to assess, represent and classify the relative magnitude of the risk of an unfavorable event happening based on the probability/damage pair of indices (IEC 31010:2019). Risk assessment matrices have a visual graphic form representing a two-dimensional classifier of risk categories. The matrices' size and structure are arbitrary and must be determined by the users in accordance with the analysis goals and conditions in each individual case (ISO 31000:2018; Smith et al., 2009; Franks and Maddison, 2006).

Fig. 1 presents an example of a risk matrix where the categories of probability/damage are represented by qualitative 5-level scales forming a classifier of risk categories $5 \times 5$ cells in size. Cells with the lowest risk level are located in the upper left corner of the matrix, cells with the highest risk level are in the bottom right corner.

\begin{tabular}{|c|c|c|c|c|c|}
\hline & \multicolumn{5}{|c|}{ Probability categories } \\
\hline Damage severity categories & A & B & C & D & E \\
\hline 1 & & & & & \\
\hline 2 & & & & & \\
\hline 3 & & & & & \\
\hline 4 & & & & & \\
\hline 5 & & & & & \\
\hline
\end{tabular}

Fig. 1. An occupational risk assessment matrix for PJSC Gazprom (where A-E are the event probability categories (in ascending order of probability), 1-5 are the event severity categories (in ascending order of damage); the color scheme of risk categories is as follows: green for low risk, yellow for medium risk, red for high risk). Source: Gazprom 18000.1-002-2014

Basic elements of risk matrices are the probability/damage scales describing the range of values for the probability/damage index from the minimum potentially significant level to the maximum possible level. Depending on the kind of probability/damage scales, two types of risk assessment matrices can be distinguished (Elmonstri, 2014):

- the qualitative risk matrix based on qualitative probability/damage scales, the values of which are expressed as verbal categories (for example, describing an event's probability with the use of terms such as "Rarely", "Frequently", "Very frequently", etc.);

- the semi-quantitative risk matrix based on numerical probability/damage scales, the values of which are expressed as quantitative or conventional numerical units (for example, describing an event's probability with the use of a range such as $0 \div 100 \%, 1 \div 5$ scores).

Matrices of the second type demonstrate a higher level of results' detail. Therefore, their use is preferable (Kabanov et al., 2019, Ni et al., 2010). The number of risk categories in such matrices is equal to the number of cells, and the numerical risk index is determined in accordance with the following expression: 


$$
R=P \cdot Q
$$

where $P$ is the negative event probability index, ea; $Q$ is the negative event damage index, ea.

Definitely, the advantages of risk matrices are as follows (IEC 31010:2019):

- the ease of use compared to other risk assessment methods, which allows for quick risk categorization for the level of significance;

- visual graphic representation of the risk significance and the probability/damage levels;

- the possibility of comparing risks with different types of consequences.

Risk matrices make it possible to provide a well-defined base for systematic analysis of the occupational risk portfolio. They can be used to make managerial decisions on different organization levels, from strategic corporate decisions to safety management in particular workplaces (Alp, 2006).

When considering the practice of matrix application for occupational risk assessment in mining enterprises, it becomes obvious that this simple tool has some noticeable drawbacks. The following overview of the risk assessment matrices' weak points has been formed based on the authors' many years of experience in the field of occupational risk assessment in mining enterprises, as well as on the results of international studies in this sphere. It should be noted that the said drawbacks may manifest themselves partially, depending on the matrix type and structure, but in the vast majority of instances, they are fully represented.

1. High subjectivity of assessments due to the impact of individual beliefs of the experts who develop the matrix and perform the occupational risk analysis (Gendler et al., 2020; Dillon et al., 2018; Duijm, 2015; Elmonstri, 2014; Smith et al., 2009; Cox, 2008). This drawback results in a high error of the results and their unsatisfactory reproducibility: on the one hand, different experts may make different assessments because of their different experience (knowledge level, complex of preconceptions, proneness to errors); on the other hand, individual variation in subjective assessments may result in one and the same expert making different assessments at different moments of time.

2. Expert assessments are influenced by cognitive biases of perception that cause most people's ability for risk assessment to deteriorate (Hubbard and Evans, 2010). Thus, in the event of a subjective probability assessment, experts often tend to overestimate low-probability and to underestimate high-probability risks (Smith et al., 2009; Tversky and Kahneman, 1992). In addition to that, high-damage and low-probability risks draw more attention compared to high-probability and low-damage risks (even in those instances where the negative impact has a cumulative effect and leads to serious delayed consequences). This drawback is especially important when assessing occupational risks associated with the impact of harmful production factors on workers, which results in the delayed emergence of severe occupational diseases.

3. Discreteness of risk matrix scales leading to a low level of the results' detail and an increased probability of occupational risks with different significance falling into one risk category (Duijm, 2015; Levine, 2012; Wall, 2011; Cox, 2008). For example, as paper (Mineur, 2017) shows, in $3 \times 3$ qualitative matrices with the "Low", "Medium" and "High" risk categories, risks with a $67 \%$ and $99 \%$ probability will fall into one category, "High Risk". However, it is obvious that risk with a $99 \%$ probability has a priority in its management compared to risk with a $67 \%$ probability. The matrix assessment methodology makes it possible to increase the number of risk categories in order to enhance the output data detail, but that leads to an increase in the matrix size (much more than $5 \times 5$ cells), which causes additional difficulties for experts when using it.

4. The simplified linear scaling of the probability/damage scales implies that the index measurement range is calculated within one and the same order of magnitude. However, the broad dynamic range of changes in the probability/damage indices indicates that each category must differ from the previous one by order of magnitude (Mineur, 2017; Duijm, 2015; Levine, 2012; Alp, 2006). It should also be mentioned that according to the empirical psychophysiological Weber-Fechner law, human perception is close to the logarithmic distribution law.

5. Equal specific weight of the probability/damage indices. A simple example can illustrate this drawback: an unfavorable event with a probability of $10 \%$ and potential damage of $\$ 10,000$ has the same risk (consequently, the same management priority) compared to an event with a probability of $0.01 \%$ and potential damage of $\$ 10,000,000$.

6. Difficulty in comparing occupational risks with diverse consequences that are associated both with the worker's injuries and with them developing occupational diseases. One identified hazard may result in a number of alternative outcomes, each one of which has to be recognized, analyzed, and managed. For example, the presence of highly toxic substances, nuclear, infrared, and other types of radiation in the workplace may lead either to an abrupt deterioration of the state of health or to the emergence of delayed consequences in the form of occupational diseases.

Papers by Duijm, 2015; Elmonstri, 2014; Hubbard and Evans, 2010; Levine, 2012; Smith et al., 2009; and Cox, 2008; present valuable recommendations on overcoming some of the aforesaid drawbacks. However, they are disjoint in nature, often involve the use of more complex models of calculating and processing the expert 
assessment results, as well as additional training for the experts (which may be unreasonable if they are hired on a single occasion). The system and in-depth analysis of the said weak points of risk matrices has served as the foundation for creating the improved method for matrix assessment, which is presented below. In addition to that, the authors have formulated clear methodological recommendations on occupational risk management based on the qualitative analysis and semi-quantitative assessment of such risks with the use of an improved matrix method.

\section{Research Methodology}

\section{Improved method for matrix occupational risk assessment.}

The key drawbacks of risk matrices are related to the assessments' subjective nature and the difficulty of making a clear choice of a probability/damage category. One possible solution to this problem is the use of continuous probability/damage scales where the intervals of the numerical probability/damage index will be bound to qualitative verbal categories. Such an approach will:

a) minimize the uncertainty in assessment selection that is inherent in the qualitative and semi-quantitative scales;

b) provide the necessary freedom in the selection of probability/damage assessments by the experts;

c) make it possible to use scales with a non-linear pattern of variable distribution in order to minimize cognitive biases when making an expert assessment.

The probability index is found with the use of the suggested method, based on the index of the expected frequency of an unfavorable event occurrence measured in the interval from 1 day $^{-1}$ to 22,000 day $^{-1}$ (which corresponds to the unfavorable event's periodicity from 1 time per day to 1 time per 60 years). In the course of regression analysis of expert assessments of the unfavorable events' expected frequency, which were unified according to the results of the authors' multi-year research in the field of occupational risk assessment, a regression model for determining the probability index $P$ has been obtained, score $(0 \leq P \leq 100)$, based on the logarithm of the unfavorable event's expected frequency $\lambda$, day ${ }^{-1}$ (correlation coefficient of the regression model $R_{c}=0.87$, determination coefficient $R^{2}=0.76$ ):

$$
P=100-10 \cdot \ln (\lambda)
$$

Fig. 2 shows the relationship $P=f(\lambda)$ where intervals are determined on the scale of the numerical probability index $P$ corresponding to the qualitative verbal categories of an unfavorable event's occurrence probability $(V H$, very high probability; $H$, high probability; $M$, medium probability; $L$, low probability; $V L$, very low probability). Table 1 presents the intervals for indices $P$ and $\lambda$ corresponding to the said verbal categories.

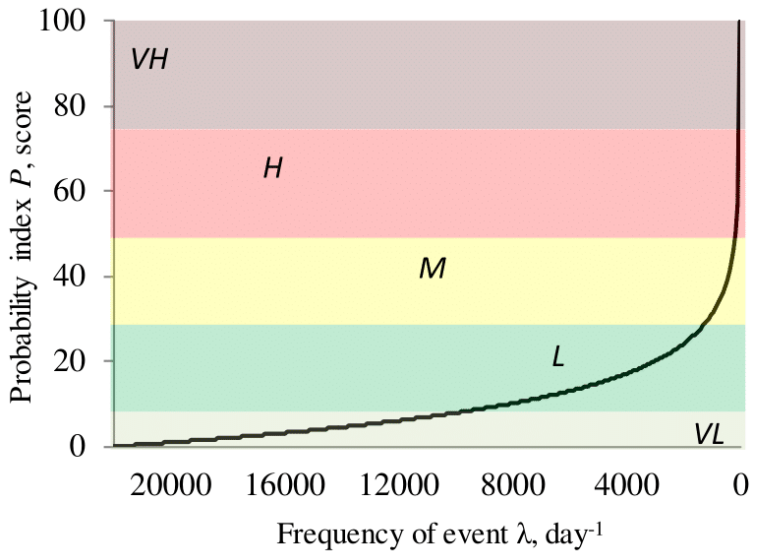

Fig.2. Assessment of an event's probability based on the expected frequency of its occurrence. Source: Author's estimations

Tab. 1. Verbal assessments of an unfavorable event's occurrence probability $P$

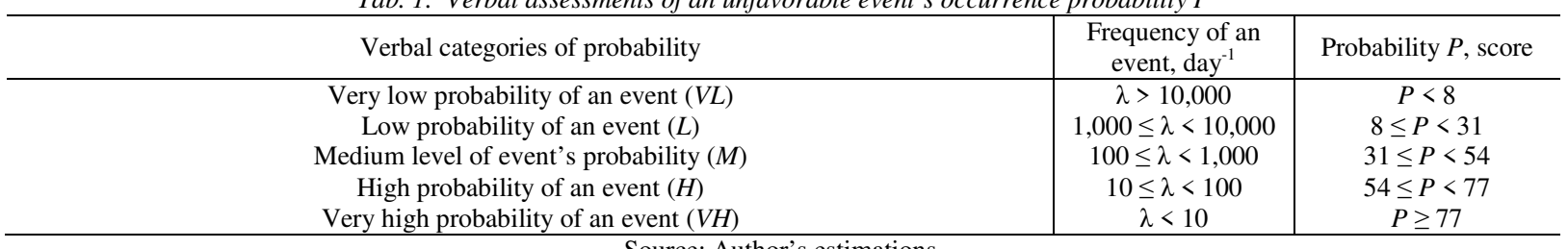

Source: Author's estimations. 
The damage index $Q$, score $(0<Q<100)$, is determined with an account of the variables that allow for using a common approach to the assessment of occupational risks of a worker getting injured and developing occupational diseases: the indices of the degree of the worker's body function impairment resulting from exposure to a hazard, $D, \%(0 \leq D \leq 100)$ (Table 2$)$, and the duration of the impairment period under consideration, $T$, day $(1 \leq T \leq 22,000)$. The relationship $Q=f(T, D)$ was formalized by using the method of multivariate regression analysis based on expert assessments, with the result that the following model was obtained (multiple correlation coefficient of the model $R_{m c}=0.81$, determination coefficient $R^{2}=0.66$ ):

$$
Q=0,65 \cdot(5,5 \ln (T)+D) .
$$

Tab. 2. Expert assessment of the degree of body function impairment

\begin{tabular}{|c|c|}
\hline Assessment criteria & Value of $D, \%$ \\
\hline Mild impairment of the body's functional state, the capacity to work is preserved & $D<20$ \\
\hline Significant impairment of the body's functional state, the capacity to work is lost & $20 \leq D<40$ \\
\hline Marked impairment of the body's functional state, the self-care ability is lost & $40 \leq D<60$ \\
\hline Very marked impairment of the body's functional state, the grave condition requires active therapy & $60 \leq D<80$ \\
\hline Critical impairment of the body's functional state, high probability of mortality & $D \geq 80$ \\
\hline
\end{tabular}
Source: Author's estimations.

Fig. 3 shows a matrix obtained based on expression 3 and allowing for rapid determination of index $Q$ using the graphical method with an account of the values of indices $T$ and $D$. Table 3 presents estimated values of the damage index $Q$ corresponding to the main types of adverse consequences (in the mining industry) in cases of exposure of the worker's body to hazards.

\begin{tabular}{|c|c|c|c|c|c|c|c|c|}
\hline Degree of body function impairment & \multicolumn{6}{|c|}{ Duration of body function impairment period $T$, day } \\
\cline { 2 - 10 }$D$ & 1 & 10 & 100 & 500 & 1000 & 5000 & 10000 & 22000 \\
\hline$<20 \%$ & 13 & 21 & 29 & 35 & 38 & 43 & 46 & 49 \\
\hline $40 \%$ & 26 & 34 & 42 & 48 & 51 & 56 & 59 & 62 \\
\hline $60 \%$ & 39 & 47 & 55 & 61 & 64 & 69 & 72 & 75 \\
\hline$>80 \%$ & 52 & 60 & 68 & 74 & 77 & 82 & 85 & 88 \\
\hline
\end{tabular}

The occupational risk index $R$, score $(0 \leq R \leq 10000)$, is determined according to expression 1 . The numerical form of the occupational risk indicator allows performing the result aggregation for a wide range of heterogeneous occupational risks, for example, using methods relying on fuzzy sets, numerical intervals, and the probability density function, which are described in detail by (Bao et al., 2019; Markowski and Mannan, 2008). Such aggregation provides users with an opportunity to obtain integral indicators of occupational risk, characterizing the working conditions both for individual workplaces and for the organization as a whole.

For the purposes of further assessment (categorization) of occupational risks, determination and justification of measures on the management of identified occupational risks, intervals corresponding to the three risk categories have been identified in the range of index $R$ (Table 4). In this respect, the number of risk categories has been determined in accordance with the three grades of controlling effects. According to the conventional approach, each category is represented by a color: green for low risk level, yellow for medium risk level, red for high risk level.

Tab. 3. Verbal assessments of damage $Q$

\begin{tabular}{|c|c|c|}
\hline $\begin{array}{l}\text { Verbal categories } \\
\text { of damage }\end{array}$ & Examples of adverse consequences & $\begin{array}{l}\text { Range of values for } \\
\text { index } Q, \text { score }\end{array}$ \\
\hline Very low damage & Microinjury (bruise, abrasion, etc.), mild allergic reaction & $Q<15$ \\
\hline Low damage & Minor injuries (limb dislocation, $1^{\text {st }}$ degree burn, laceration, etc.) & $15 \leq Q<30$ \\
\hline $\begin{array}{l}\text { Medium level of } \\
\text { damage }\end{array}$ & $\begin{array}{c}\text { Moderately severe injuries (closed fracture of a limb, } 2^{\text {nd }} \text { degree burn, brain concussion, etc.), } \\
\text { mild to moderate occupational diseases }\end{array}$ & $30 \leq Q<50$ \\
\hline High damage & $\begin{array}{l}\text { Severe injuries (open fracture of a limb, rib fractures, } 3^{\text {rd }} \text { to } 4^{\text {th }} \text { degree thermal burn, traumatic } \\
\text { pneumothorax, etc.), severe occupational diseases }\end{array}$ & $50 \leq Q<75$ \\
\hline $\begin{array}{l}\text { Very high } \\
\text { damage }\end{array}$ & $\begin{array}{l}\text { Very severe injury (craniocerebral injury, spine injury, inner organ rupture, injuries of both } \\
\text { eyes, great vessel injuries, etc.), acute poisonings, and occupational diseases with a high } \\
\text { probability of mortality }\end{array}$ & $Q \geq 75$ \\
\hline
\end{tabular}
Source: Author's estimations. 


\begin{tabular}{|c|c|c|}
\hline Occupational risk category & Range of values for index $R$, score & $\begin{array}{l}\text { The necessity for the implementation of } \\
\text { controlling effects in the process of risk } \\
\text { management }\end{array}$ \\
\hline $\begin{array}{l}\text { Low level of risk } \\
\text { (unacceptable risk) }\end{array}$ & $R<600$ & $\begin{array}{c}\text { Implementation of additional protective } \\
\text { measures is not required }\end{array}$ \\
\hline $\begin{array}{l}\text { Medium level of risk } \\
\text { (unacceptable risk) }\end{array}$ & $600 \leq R<2,350$ & $\begin{array}{l}\text { Implementation of protective measures } \\
\text { /active control over the performance of } \\
\text { previously implemented protective } \\
\text { measures is required; hazard monitoring is } \\
\text { mandatory }\end{array}$ \\
\hline $\begin{array}{l}\text { High level of risk } \\
\text { (unacceptable risk) }\end{array}$ & $R \geq 2,350$ & $\begin{array}{c}\text { The work process must be paused till the } \\
\text { additional protective measures are } \\
\text { implemented; hazard monitoring is } \\
\text { mandatory }\end{array}$ \\
\hline
\end{tabular}

Fig. 4 presents a surface that visually demonstrates the non-linear nature of the relationship $R=f(\lambda, Q)$.

Fig. 5 shows a graphic representation of a two-dimensional risk matrix that represents the relationship $R=f(P, Q)$ and allows for occupational risk assessment using the graphical method with the aid of continuous probability/damage scales.

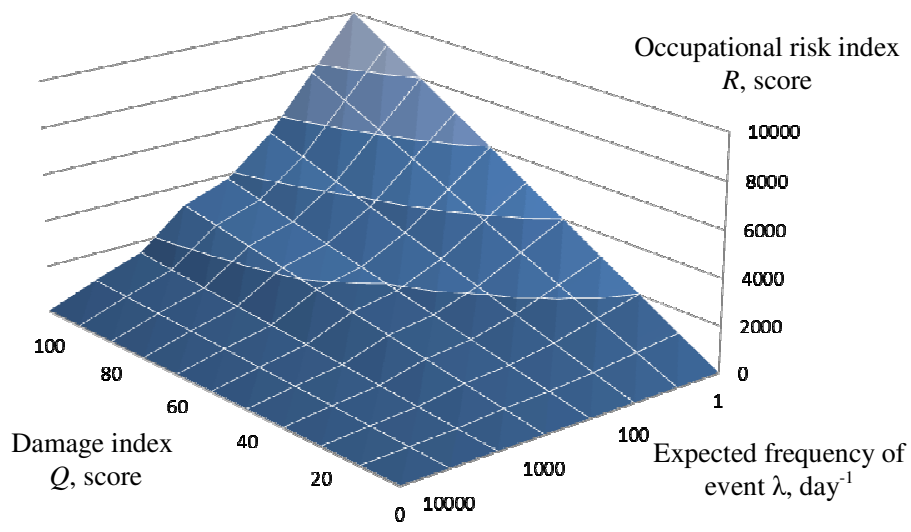

Fig. 4. Surface plot of the function $R=f(\lambda, Q)$. Source: Author's estimations

\begin{tabular}{|c|c|c|c|c|c|c|c|c|c|c|c|}
\hline \multirow{2}{*}{$\begin{array}{c}\text { Damage index } \\
Q, \text { score }\end{array}$} & \multicolumn{11}{|c|}{ Probability index $P$, score } \\
\hline & 0 & 10 & 20 & 30 & 40 & 50 & 60 & 70 & 80 & 90 & 100 \\
\hline \multicolumn{12}{|l|}{0} \\
\hline \multicolumn{12}{|l|}{10} \\
\hline \multicolumn{12}{|l|}{20} \\
\hline \multicolumn{12}{|l|}{30} \\
\hline \multicolumn{12}{|l|}{40} \\
\hline \multicolumn{12}{|l|}{50} \\
\hline \multicolumn{12}{|l|}{60} \\
\hline \multicolumn{12}{|l|}{70} \\
\hline \multicolumn{12}{|l|}{80} \\
\hline \multicolumn{12}{|l|}{90} \\
\hline 100 & & & & & & & & & & & \\
\hline
\end{tabular}

Fig. 5. Graphical form of the occupational risk assessment matrix obtained. Source: Author's estimations

\section{The methodology of occupational risk assessment.}

Occupational risk assessment is only a necessary stage on the way to elaborating managerial decisions aimed at minimization of hazards, protection of the workers' life and health (Kuletskiy et al., 2020; Filimonov and Gorina, 2019). In this respect, it is to be understood that risk is more than a mere probability of an unfavorable event's occurrence and its damage; it is also a set of factors representing the causes and conditions of an unfavorable event's implementation. Therefore, to determine a package of occupational risk management measures, it is necessary to involve somewhat more complete data in the analysis than what an occupational risk assessment matrix can provide.

Fig. 6 presents an algorithm for information collection and registration (formed in accordance with standards IEC 31010:2019, ISO 31000:2018), which allows for elaborating managerial decisions in the occupational risk management system framework. Table 5 presents the occupational risk map's recommended 
structure, which is filled as information is collected when performing the occupational risk management stages listed below (acc. to Fig. 6).

Stage 1, "Definition of the Situation", includes the formulation of the organization's goals in the field of occupational risk management (with an account of external and internal conditions), as well as the selection of objects for further analysis.

Stage 2, "Risk Identification", is aimed at the identification of all possible harmful and hazardous production factors in the workplace, as well as hazardous situations that can lead to a worker getting injured or developing occupational diseases. The following data should be used as initial information when performing risk identification: the results of a visual inspection of the workplace and the analysis of work processes executed in it, workers' reports on any hazard sources previously identified by them, records of investigations of the circumstances and causes of any workplace accidents, results of occupational risk identification in similar workplaces, and other data.

Stage 3, "Risk Analysis", provides input information for further risk assessment and includes identification of possible hazardous events, which, on the one hand, result from the identified risks' existence, and on the other hand, lead to workers getting injured or developing occupational diseases. At the risk analysis stage, it is extremely important to identify the causes and conditions of hazardous events' occurrence because this information constitutes the basis for the elaboration of occupational risk management measures. Identification of hazardous events, as well as of the causes and conditions of their occurrence, results in making a list of scenarios of the hazards' negative impact on workers.

Stage 4, "Risk Assessment", involves calculating the occupational risk index (according to expressions 1-3 or Fig. 5) in relation to each identified scenario of hazard sources' negative impact on the worker. After that, a decision is made with respect to the need for further treatment of each assessed risk (by way of determining the risk category with the aid of Table 5) and distribution of risk management priorities based on risk ranking by index R. When assessing risks, it should be kept in mind that each scenario of negative impact may result in different alternative outcomes implicating different damage for the worker's life and health.

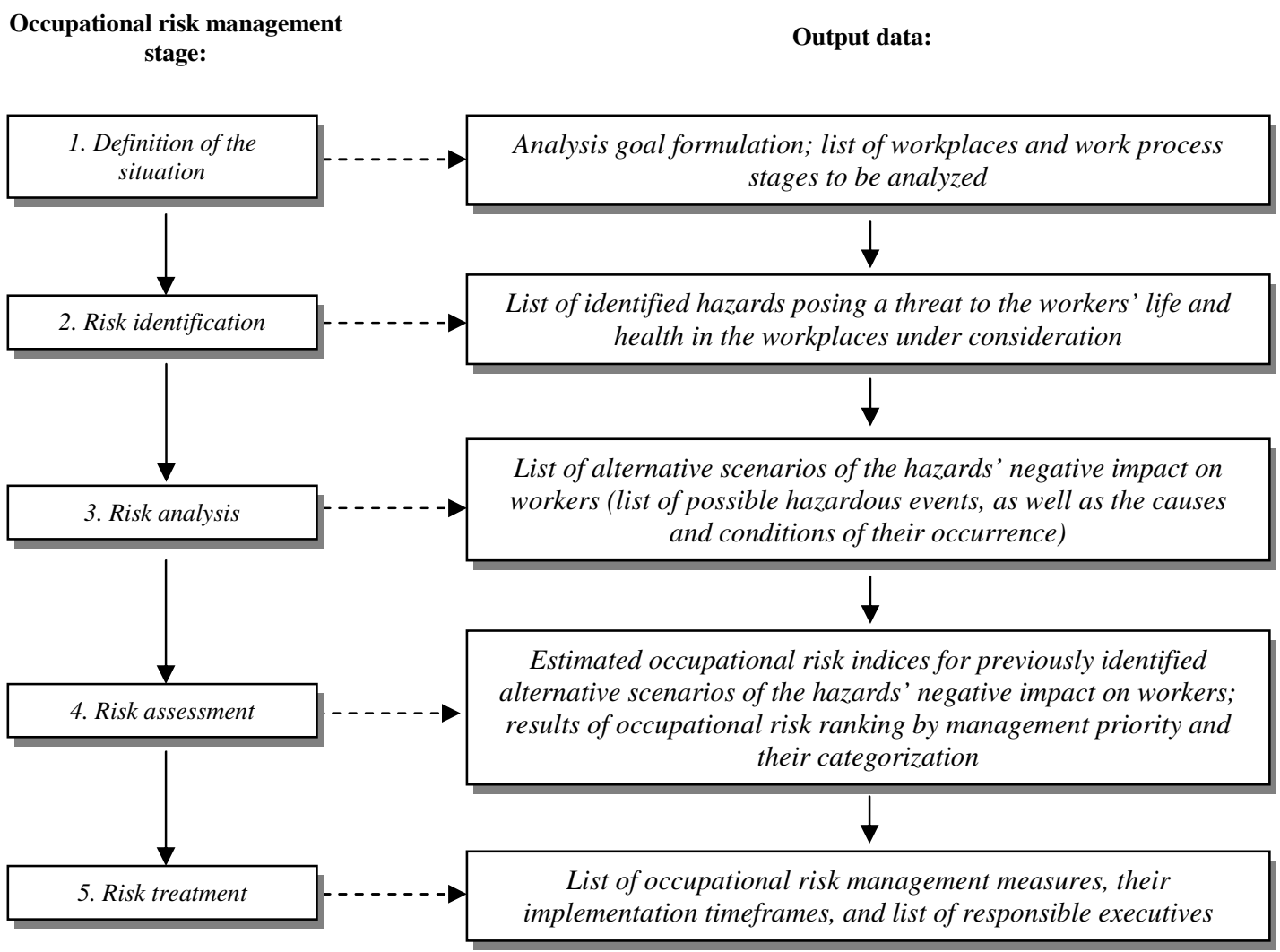

Fig. 6. The main stages of occupational risk management. Source: Author's estimations 
Tab. 5. Occupational risk map structure

\begin{tabular}{|c|c|c|}
\hline No. & Name of item & Description of item \\
\hline 1 & Workplace & Provide the name of the workplace under analysis \\
\hline 2 & Work process stage & $\begin{array}{c}\text { Provide the name of the work process stage under analysis, which is implemented in the workplace } \\
\text { under consideration }\end{array}$ \\
\hline 3 & Hazard source & $\begin{array}{c}\text { Provide the identified harmful/hazardous production factors or hazardous situations specific to the } \\
\text { work process stage under consideration }\end{array}$ \\
\hline 4 & Hazardous event & $\begin{array}{c}\text { Provide the hazardous events possible for the work process stage under consideration, which result } \\
\text { in a negative impact of the hazard source on the worker }\end{array}$ \\
\hline 5 & Cause of hazard & Provide the possible causes for the occurrence of the hazardous event under consideration \\
\hline 6 & Hazardous conditions & $\begin{array}{l}\text { Provide the possible unfavorable conditions for the occurrence of the hazardous event under } \\
\text { consideration that increase the probability/damage of the hazard source's negative impact on the } \\
\text { worker }\end{array}$ \\
\hline 7 & Probability index & Provide the probability index $P$ (acc. to expression 2$)$ \\
\hline 8 & Damage index & Provide the damage index $Q$ (acc. to expression 3) \\
\hline 9 & Risk index & $\begin{array}{c}\text { Provide the occupational risk index } R \text { (acc. to expression } 2 \text { ) and the occupational risk assessment } \\
\text { (category) (acc. to Table } 4 \text { ) for the scenario of a negative impact of the hazard source on the worker } \\
\text { under consideration }\end{array}$ \\
\hline 10 & Management measures & $\begin{array}{c}\text { Provide the occupational risk management measures in relation to the scenario of a negative impact } \\
\text { of the hazard source on the worker under consideration }\end{array}$ \\
\hline 11 & Responsibility assignment & $\begin{array}{l}\text { Provide the names of persons responsible for the implementation of occupational risk management } \\
\text { measures, as well as their implementation timeframes }\end{array}$ \\
\hline
\end{tabular}

In order to consider all possible alternatives to adverse consequences, it is recommended to build risk profiles in the coordinates $R=f(Q)$. Thus, the risk profile presented in Fig. 7 demonstrates alternative outcomes of the hazard of an open-pit haul truck driver falling from the height of the haul truck deck in the process of shift handover.

This negative event may result in injuries of various degrees of severity, each one of which is characterized by different probability indices, and consequently, different occupational risk indices. The risk profile presented here visually represents the occupational risk levels for each one of the alternative outcomes and allows for establishing the maximum occupational risk index for the given hazardous event (acc. to Fig. $7, R^{\mathrm{max}}=935$ scores).

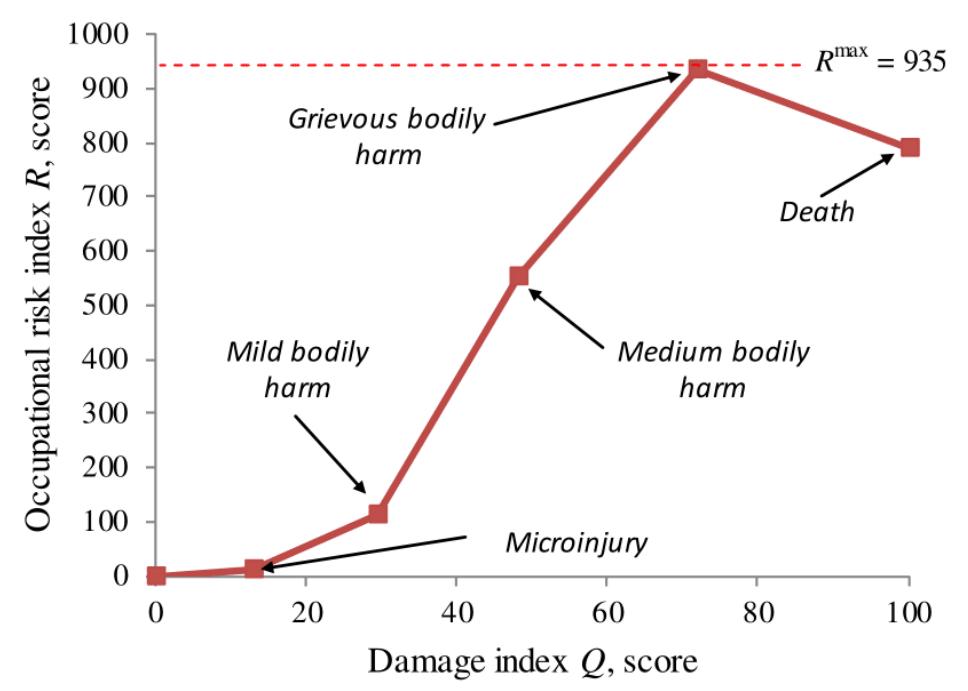

Fig. 7. An example of an occupational risk profile. Source: Author's estimations

Risk profiles can be a useful tool for visual comparison of different occupational risks when making managerial decisions. Fig. 8 shows an example of risk profiles for alternative consequences of hazardous events resulting from the existence of a hazard source (staying in a moving haul truck). 


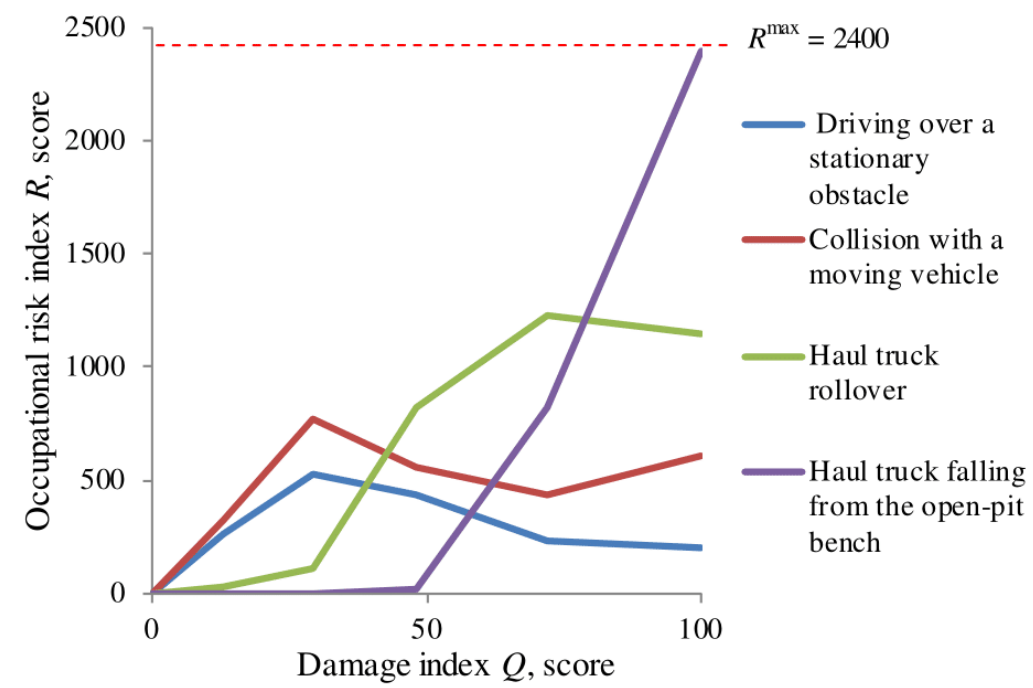

Fig. 8. An example of a comparison of a hazard's alternative outcomes with the use of risk profiles (hazard source: staying in a moving haul truck). Source: Author's estimations

Stage 5, "Risk Treatment", includes determining different variants of risk management (protective measures), as well as planning of risk management actions. In such a case, the organization's resources must be distributed with the account of the priority in managing different occupational risks (because occupational risks with the highest value of index $R$ require more attention).

As mentioned above, the occupational risk management measures are determined based on the analysis of the causes and conditions of hazardous events under consideration. In the context of mining organizations' specific features, the possible occupational risk management measures can be as follows:

- hazard elimination (for example, resulting from workplace modernization, cancellation of individual stages of the work process, etc.);

- measures to reduce the hazardous event occurrence probability and/or potential damage, aimed at prevention of arising of causes and conditions for a hazardous event's occurrence (for example, for technical causes they involve equipment repair and replacement, or changes in the production process; for organizational causes, enhancing the control over production process execution, the workers' training, application of disciplinary measures, etc. (Nikulin et al., 2019);

- measures to reduce the hazardous event occurrence probability and/or potential damage, aimed at improving the worker's protection against the hazard sources' negative impact (for example, implementing automated safety systems, additional protective barriers, and providing the workers with personal protection equipment, etc.).

Planning of the selected occupational risk management measures includes determining a group of persons responsible for their implementation, as well as establishing the timeframes for their implementation. A mandatory procedure following the implementation of risk management measures is residual risk assessment (similarly to Stage 4), which results in making a decision in relation to the protective measures' efficiency and a need for their correction (Nikulin and Nikulina, 2017). In the event that the occupational risk has been reduced to acceptable values, the organization's resources must be directed at minimizing occupational risks with a lower management priority.

\section{Results and Discussion}

The objects for the approbation of the improved method for matrix occupational risk assessment and the suggested procedure for making decisions on occupational risk management were workplaces in an operating open-pit coal mine. The expert group that performed the analysis included acting specialists of the enterprise under consideration and representatives of industry universities.

The analysis objects were workplaces of haul truck drivers, excavator operators, drill runners, and mine machinery repairmen (the total number of workplaces analyzed was equal to 44). In relation to the workplaces, the experts established the stages of the work process, each of which underwent a risk identification procedure.

In accordance with the algorithm presented in Fig. 6, the goal of the analysis was also formulated at the initial stage, which consisted in:

- determining any occupational risks in workplaces categorized as unacceptable occupational risk ("High Risk" category acc. to Table 4);

- ranking these risks in order of management priority; 
- making a list of occupational risk management measures, timeframes for their implementation, and responsible executives.

In the course of risk identification in relation to each work process stage in each workplace, an analysis of labor conditions was performed, which resulted in hazard source identification in quantity presented in Table 6.

\begin{tabular}{c|ccccc}
\multicolumn{6}{c}{ Tab. 6. Result of hazard source identification in workplaces } \\
\hline Workplaces & \multicolumn{5}{c}{ Number of hazard sources, pcs } \\
& Physical & Electrotechnical & Chemical & Climatic & Biological \\
\hline Haul truck drivers & 10 & 1 & 2 & 2 & - \\
Excavator operators & 5 & 3 & 1 & 1 & - \\
Drill runners & 6 & 1 & 3 & 3 & - \\
Mine machinery repairmen & 11 & 4 & 3 & - & 1 \\
\hline
\end{tabular}

Risks were identified with the account of visual workplace inspection results, the register of identified violations of safety rules and precautions, and analysis of the standards for technological operation performance in workplaces.

The expert group implemented the hazard analysis stage with the use of the brainstorming technique, which resulted in the identification of 276 possible scenarios of the identified hazard sources' negative impact on workers. As an example, Fig. 9 presents a fragment of a risk map (according to Table 5) demonstrating 4 alternative scenarios of the impact of the hazard source under consideration (hazardous situation), "Staying in a moving haul truck".

In the course of risk assessment for each one of the identified scenarios, the occupational risk index $R$ was calculated (expression 1), for which purpose expert assessment of the parameters $\lambda, D$, and $T$ was performed, with subsequent calculation of the indices $P$ and $Q$ (expressions 2 and 3). The obtained results were included in the risk map (Fig. 7) and used to categorize occupational risks and determine management priorities. According to the results of risk assessment and categorization, the total number of scenarios, which fell into the "High Risk" category, was equal to 52 .

In the risk assessment process, the experts built risk profiles (an example is presented in Fig. 8), which were also used in the reporting materials to compare different occupational risks visually.

In accordance with the analysis's goal, all occupational risks categorized as "High Risk" were further considered by the expert group to determine the list of management measures (protective measures).

\begin{tabular}{|c|c|c|c|c|c|c|c|c|}
\hline Workplace & $\begin{array}{l}\text { Work process } \\
\text { stage }\end{array}$ & Hazard source & Hazardous event & Cause of hazard & Hazardous conditions & $\begin{array}{c}\text { Probability } \\
\text { index }\end{array}$ & $\begin{array}{c}\text { Damage } \\
\text { index }\end{array}$ & $\begin{array}{l}\text { Risk } \\
\text { index }\end{array}$ \\
\hline 1 & 2 & 3 & 4 & 5 & 6 & 7 & 8 & 9 \\
\hline \multirow{4}{*}{$\begin{array}{l}\text { Haul truck } \\
\text { driver }\end{array}$} & \multirow{4}{*}{$\begin{array}{l}\text { Rock mass } \\
\text { transportation }\end{array}$} & \multirow{4}{*}{$\begin{array}{l}\text { Staying in a } \\
\text { moving haul } \\
\text { truck }\end{array}$} & $\begin{array}{l}\text { Injury caused by haul } \\
\text { truck falling from the } \\
\text { open-pit bench }\end{array}$ & $\begin{array}{l}\text { 1. Brake system failure } \\
\text { 2. Haul truck movement } \\
\text { down a slope }\end{array}$ & $\begin{array}{l}\text { 1. Insufficient height of } \\
\text { protection } \\
\text { embankment } \\
\text { 2. Presence of road } \\
\text { icing }\end{array}$ & 24 & 100 & $\begin{array}{c}2400 \\
\text { (high risk) }\end{array}$ \\
\hline & & & $\begin{array}{l}\text { Injury caused by haul } \\
\text { truck rollover }\end{array}$ & 1. Overspeeding & $\begin{array}{l}\text { 1. Presence of road } \\
\text { humps }\end{array}$ & 17 & 72 & $\begin{array}{l}1227 \\
\text { (medium } \\
\text { risk) }\end{array}$ \\
\hline & & & $\begin{array}{c}\text { Injury caused by } \\
\text { collision with moving } \\
\text { vehicle }\end{array}$ & $\begin{array}{l}\text { 1. Violation of traffic } \\
\text { rules }\end{array}$ & $\begin{array}{l}\text { 1.Nighttime } \\
\text { 2. Absence of priority } \\
\text { traffic signs }\end{array}$ & 26 & 29 & $\begin{array}{l}772 \\
\text { (medium } \\
\text { risk) }\end{array}$ \\
\hline & & & $\begin{array}{l}\text { Injury caused by driving } \\
\text { over a stationary obstacle }\end{array}$ & $\begin{array}{l}\text { 1. Haul truck driver's } \\
\text { individual negligence }\end{array}$ & $\begin{array}{l}\text { 1. Nighttime } \\
\text { 2. Haul truck's lighting } \\
\text { failure }\end{array}$ & 18 & 29 & $\begin{array}{l}530 \\
\text { (low risk) }\end{array}$ \\
\hline
\end{tabular}

According to the assessment results, the highest management priority among all the identified risks was assigned to the risk with the maximum value $R^{\max }=2400$ scores (corresponding to the scenario where the haul truck driver gets injured as a result of the haul truck falling from the open-pit bench due to the brake system's failure and the presence of hazardous conditions, such as the insufficient height of the bench's protection embankment and presence of icing on the pit road) $\left(R^{\max }\right.$ was determined when analyzing the risk profile in Fig. 8). For this scenario, the expert group has recommended the following occupational risk management measures:

1) maintenance of the haul truck's brake system in good working condition;

2) an unscheduled inspection of the open-pit haul trucks' technical condition;

3 ) enhancement of control over the observance of maintenance regulations for the mine machinery;

4) application of disciplinary measures on the technological transport shop manager;

5) prohibition of mine machinery operation without non-skid chains when there is road icing; 
6) bringing the protection embankment on the open pit benches and the pit roads into compliance with the project documentation.

The final stage of managerial decision making involved determining the timeframes for enforcement of the regulations on occupational risk management (with the account of risk ranking by management priority) and assignment of responsibility for their observance (with the account of the employees' and the organization unit's authorities).

In relation to a number of hazardous events' occurrence scenarios, in addition to the suggested methodological approach to risk assessment, the expert group also used a standard risk matrix, $5 \times 5$ cells in size (Fig. 1). Thus, the results' comparison had demonstrated that when the standard risk assessment matrix was used, the greatest number of hazardous events was included in the most indifferent category, "Medium risk level" (81\% vs $53 \%$ for haul truck drivers, $74 \%$ vs $55 \%$ for excavator operators, $75 \%$ vs $47 \%$ for drill runners, $85 \%$ vs $64 \%$ for mine machinery repairmen). The use of quantitative and unambiguously interpreted function arguments $P$ and $Q$ in the suggested method has made it possible to minimize the selection uncertainty in the process of expert assessment, which resulted in categorizing the greater part of hazardous events as "Low Risk" and "High Risk". That allowed for excluding hazards with a negligible level of risk from the analysis and focusing the expert group's resources on working with hazard sources having the highest management priority. As a consequence, when using the suggested method, the experts were able to formulate the greatest number of targeted recommendations on occupational risk management in workplaces (42\% more, on average). The said result is indicative of an enhancement in the efficiency of using organizational resources to elaborate on targeted protective measures. According to the approbation results, in addition to the possibility for a more subtle analysis of hazard sources that was shown here, the expert group also noted an enhancement in the convenience of using the suggested calculation algorithms for the analysis of diverse occupational risks.

\section{Conclusion}

Any attempts to restrict the use of risk matrices for occupational risk analysis are often futile as the assessment groups' resources are limited. For this reason, in many instances, experts have to use the matrix assessment method and often see it as the only possible one. The ways to overcome the drawbacks of the classical matrix risk assessment suggested by the authors have made it possible to develop a new methodological approach that allows for overcoming the risk matrices' weak points to a significant extent, as well as for preserving the simplicity and visibility of the matrix assessment method. One of the most significant results of this study is the creation of an algorithm to calculate the occupational risk index that makes it possible to:

a) reduce the subjectivity of the analysis results and minimize the occurrence of cognitive biases during expert assessment due to using intuitively comprehensible continuous variables of probability/damage (the expected frequency of an unfavorable event's occurrence, the degree, and duration of the worker's body function impairment) as input variables;

b) enhance the output data detail level and overcome the discreteness of risk matrices' simplified linear scales by way of using regression models to calculate the occupational risk index based on the variables' logarithmic continuous distribution;

c) use a common approach to the analysis, correlation, and intercomparison of occupational risks with diverse types of consequences (injuries of various degrees of severity, diseases, poisonings, etc.), based on recognition of universal input variables of probability/damage and graphical analysis of occupational risk profiles.

The paper also provides recommendations for inventory and systematization of information for occupational risk assessment purposes, which make it possible to elaborate a well-defined mechanism for managerial decision-making in the occupational risk management system to form a foundation for optimizing the use of assessment groups' resources. The developed methodology of occupational risk assessment and management lends itself to further research aimed at the risk-based analysis of working conditions at mining enterprises, as well as to the development of software for occupational health and industrial safety management.

Despite the fact that the suggested methodology has been created with respect to mining organizations' specific features, it can also be used in other branches of the industry under the condition that a justification of the possibility of its use is provided in each individual case. Alongside that, when performing an occupational risk assessment, significant attention must be paid to the experts' qualifications and the quality of the initial information, as these factors have a high impact on the suggested tool's efficiency.

\section{References}

Alp, E. (2006). Risk Matrices - The Good, the Bad, and the Ugly. Air \& Waste Management Association 2006 Annual Conference. 
Balovtsev, S.V., Skopintseva O.V., Kolikov K. S. (2020) Aerological risk management in designing, operation, closure and temporary shutdown of coal mines. Mining Informational and Analytical Bulletin, 6, 85-94. http://dx.doi.org/10.25018/0236-1493-2020-6-0-85-94.

Bao, C., Wan, J., Wu, D., Li, J. (2019). Aggregating risk matrices under a normative framework. Journal of Risk Research, 1-17. http://dx.doi.org/10.1080/13669877.2019.1588912.

Company Standard Gazprom 18000.1-002-2014 Hazard Identification and Riask Management.

Cox, L.A. (2008). What's Wrong with Risk Matrices? Risk Analysis, 28(2), $497-512$. http://dx.doi.org/10.1111/j.1539-6924.2008.01030.x.

Dillon, R.L., Klein, G.A., Rogers, E.W., Scolese, C.J. (2018). Improving the use of risk matrices at NASA. 2018 IEEE Aerospace Conference. http://dx.doi.org/10.1109/aero.2018.8396382.

Duijm, N. J. (2015). Recommendations on the use and design of risk matrices. Safety Science, 76, 21-31. http://dx.doi.org/10.1016/j.ssci.2015.02.014.

Elmonstri, M. (2014) Review of the strengths and weaknesses of risk matrices. Journal of Risk Analysis and Crisis Response, 4(1), 49-57.

Filimonov, V.A. and Gorina, L.N. (2019) Development of an Occupational Safety Management System Based On the Process Approach. Journal of Mining Institute, 235(1), 113-122. DOI: 10.31897/pmi.2019.1.113.

Franks, A.P. and Maddison, T. (2006) A simplified method for the estimation of individual risk. Process Safety and Environmental Protection, 84(2), 101-108. http://dx.doi.org/ 10.1205/psep.04287.

Gendler, S.G., Rudakov, M.L., Falova, E.S. (2020) Analysis of the risk structure of injuries and occupational diseases in the mining industry of the Far North of the Russian Federation. Naukovyi Visnyk Natsionalnoho Hirnychoho Universytetu, 3, 81 - 85. http://dx.doi.org/10.33271/nvngu/2020-3/081.

Hubbard, D. and Evans, D. (2010). Problems with scoring methods and ordinal scales in risk assessment. IBM Journal of Research and Development, 54(3), 2:1-2:10. http://dx.doi.org/10.1147/jrd.2010.2042914.

IEC 31010:2019 «Risk Management - Risk Assessment Techniques», NEQ.

ISO 31000:2018 «Risk management - Guidelines», IDT.

Kabanov, E.I., Korshunov, G.I., Gridina, E.B. (2019) Algorithmic provisions for data processing under spatial analysis of risk of accidents at hazardous production facilities. Naukovyi Visnyk Natsionalnoho Hirnychoho Universytetu, 6, 117 - 121. http://dx.doi.org/10.29202/nvngu/2019-6/17.

Kazanin, O.I., Rudakov, M.L., Kolvah, K.A. (2018) Occupational safety and health in the sector of coal mining. International Journal of Civil Engineering and Technology, 9(6), 1333-1339.

Kuletskiy, K.V., Zhunda, S.V., Rudakov, M.L., Pasynkov, A.V., Sobyanin, D.S. (2020) Use of occupational risk management procedure with the aim of improving training on occupational safety for the employees of the open-pit coal mining organizations. Bezopasnost Truda v Promyshlennosti, 2, 74-79. http://dx.doi.org/10.24000/0409-2961-2020-2-74-79.

Levine, E.S. (2012) Improving risk matrices: the advantages of logarithmically scaled axes. Journal of Risk Research, 15(2), 209-222. http://dx.doi.org/10.1080/13669877.2011.634514.

Markowski, A.S. and Mannan, M.S. (2008). Fuzzy risk matrix. Journal of Hazardous Materials, 159(1), 152157. http://dx.doi.org/10.1016/j.jhazmat.2008.03.055.

Mineur, J. (2017) Why the risk matrix must die. URL: https://medium.com/@JornMineur/why-the-risk-matrixmust-die-620a7287e7c.

Ni, H., Chen, A., Chen, N. (2010) Some extensions on risk matrix approach. Safety Science, 48(10), 1269-1278. http://dx.doi.org/10.1016/j.ssci.2010.04.005.

Nikulin, A., Ikonnikov, D., Dolzhikov, I. (2019) Increasing labour safety on coal mines. International Journal of Emerging Trends in Engineering Research, http://dx.doi.org/10.30534/ijeter/2019/197122019.

Nikulin A.N. and Nikulina A.Y. (2017) Assessment of occupational health and safety effectiveness at a mining company. Ecology, Environment and Conservation, 23(1), 351-355.

Noskov, V.A., Badtiev, B.P., Pavlovich, A.A. (2020) Risk management in open pit mining. Gornyi Zhurnal, 2, 51-55. http://dx.doi.org/10.17580/gzh.2020.02.06.

Pelipenko, M.V., Balovtsev S.V., Aynbinder I.I. (2019) Integrated accident risk assessment in mines. Mining Informational and Analytical Bulletin, 11, 180-192. http://dx.doi.org/10.25018/0236-1493-2019-11-0180-192.

Rudakov, M.L., Kolvakh, K.A., Derkach, I.V. (2020) Assessment of environmental and occupational safety in mining industry during underground coal mining. Journal of Environmental Management and Tourism, 3(11), 579-588. DOI: http://dx.doi.org/10.14505//jemt.v11.3(43).10.

Semenov, A.S. and Kruk, M.N. (2017) Project risk analysis and management decision-making in determining the parameters of ore quarries. Journal of Industrial Pollution Control, 33(1), 1024-1028.

Skopintseva, O.V. and Balovtsev S.V. (2020) Evaluation of the influence of aerodynamic aging of production on aerological risks on coal mines. Mining Informational and Analytical Bulletin, 6(1), 74-83. http://dx.doi.org/10.25018/0236-1493-2020-61-0-74-83. 
Smith, E.D., Siefert, W.T., Drain, D. (2009). Risk matrix input data biases. Systems Engineering, 12(4), 344360. http://dx.doi.org/10.1002/sys.20126.

Tversky, A. and Kahneman, D. (1992) Advances in prospect theory: Cumulative representation of uncertainty. Journal of Risk and Uncertainty, 5, 297-323. http://dx.doi.org/10.1007/BF00122574.

Wall, K.D. (2011) The trouble with risk matrices. URL: https://calhoun.nps.edu/handle/10945/32570. 